\title{
ADAPTASI SIARAN RADIO FM DI MASA PANDEMI COVID-19
}

\author{
Caka Gatot Priambodo \\ Program Studi Teknik Informatika, Fakultas Teknik dan Ilmu Komputer, \\ Universitas Indraprasta PGRI \\ Jl. Raya Tengah Kel. Gedong, Pasar Rebo - Jakarta Timur 13760 \\ cgpriambodo@gmail.com
}

\begin{abstract}
Abstrak
Masa pandemi Covid-19 yang melanda dunia saat ini membuat jasa penyiaran radio FM komersil di Indonesia yang sangat ditentukan oleh produksi kualitas program siaran, jumlah durasi siaran maupun kuantitas siaran harus mampu beradaptasi dalam keberlangsungan siaran radio FM nya. Untuk mendukung kegiatan siaran radio FM secara nasional di masa pandemi Covid-19 yang mengharuskan perusahaan radio FM meminimalisir jumlah karyawan yang datang ke kantor maka skema yang diberlakukan yakni memaksimalkan sumber daya jaringan radio FM yang tersebar di beberapa kota besar di Indonesia dalam format siaran nasional radio FM. Format siaran nasional radio FM ini menggunakan perangkat Comrex Access Portable dan Feenphone untuk pengiriman audio dari luar studio onair menuju stasiun transmisi pemancar radio FM. Comrex Access Portable dan Feenphone memiliki kemampuan menggunakan jaringan IP (Internet Protocol). Comrex Access Portable menggunakan teknologi BRIC (Broadcast Reliable Internet Codec) yakni sebuah terobosan teknologi dengan perangkat keras yang akan mengirimkan audio melalui internet. FeenPhone adalah perangkat lunak tanpa biaya yang membuka kemungkinan secara global dunia untuk memproduksi media suara berkualitas tinggi secara real-time dari jarak mana pun. FeenPhone melakukan cara komunikasi dengan kualitas terdesentralisasi full duplex secara real-time dengan tanpa biaya.
\end{abstract}

Kata Kunci : Radio FM, Internet Protokol, Comrex Access Portable, FeenPhone, Covid-19

\begin{abstract}
During the Covid-19 pandemic that hit the world today, make commercial FM radio broadcasting services in Indonesia are largely determined by the production of broadcast program avality, the amount of broadcast duration and the avantity of broadcasts must be able to adapt to the continuity of it's FM radio broadcasts. To support FM radio broadcast activities nationally during the Covid-19 pandemic, which requires FM radio companies to minimize the number of employess coming to the office, the scheme is in place to maximize FM radio network resources spread across several mayor cities in Indonesian format in a national broadcast FM radio. This FM radio national broadcast format uses the device Comrex Access Portable and FeenPhone for sending audio from outside the studio onair to the FM radio transmitter transmission station. Comrex Access Portable to using technology BRIC (Broadcast Reliable Internet Codec) that is a breakthrough technology with hardware that will deliver audio over the public internet. FeenPhone is nocost software that opens up a global world of possibilities for real time high quality voice media production, over any distance. FeenPhone makes away communication with ultra high quality full duplex decentralized talk communication in real time for free.
\end{abstract}

Key words: FM Radio, Internet Protocol, Comrex Access Portable, FeenPhone, Covid-19

\section{PENDAHULUAN}

Tahun 2020 merupakan tahun yang sangat berat bagi dunia khususnya suatu negara dimana virus Corona atau Covid-19 telah melumpuhkan hampir seluruh sendi kehidupan manusia di negaranya yang berimbas pada penurunan ekonomi negara. Mulai dari sektor kesehatan, sektor pendidikan, sektor industri, dan sektor pariwisata terdampak langsung akibat pandemi Covid-19. Hal ini mengakibatkan suatu negara harus beradaptasi dalam keadaan pandemi Covid-19 ini yang kemungkinan kedepannya akan berlangsung dalam waktu yang lama. Adaptasi di tengah keadaan pandemi Covid-19 juga diimplementasikan oleh jasa penyiaran radio FM komersil di Indonesia, seperti pada Radio Elshinta FM 90 MHZ Jakarta. Sesuai dengan peraturan pemerintah Indonesia yang mengharuskan setiap perusahaan menerapkan protokol kesehatan dalam aktivitas usahanya, maka siaran radio FM komersil menerapkan skema siaran radio FM secara nasional yang pada prinsipnya menggabungkan jaringan radio FM nya yang dimiliki perusahaan radio FM tersebut di beberapa kota besar di Indonesia seperti Jakarta, Bandung, Semarang, dan Surabaya. Skema format 
siaran radio FM secara nasional ini dilaksanakan agar tidak terjadi kerumunan orang dalam jumlah yang banyak di area kantor atau perusahaan sehingga dapat meminimalisir penyebaran virus Corona atau Covid-19 di area kantor atau perusahaan radio FM komersil. Koneksi siaran radio FM secara nasional ini menggunakan media jaringan IP (Internet Protocol) audio yang akan dipancarkan melalui frekuensi radio FM masing-masing kota besar.

FM (Frequency Modulation) merupakan kasus khusus dari modulasi sudut. Dalam sistem modulasi sudut frekuensi dan fasa dari gelombang pembawa berubah terhadap waktu menurut fungsi dari sinyal yang dimodulasikan. Jadi, dalam FM sinyal modulasi yang di modulasikan akan menyebabkan frekuensi dari gelombang pembawa berubah-ubah sesuai peruabahan frekuensi dari sinyal modulasi. Dalam siaran FM, gelombang harus memiliki perubahan frekuensi yang sesuai dengan amplitudo dari sinyal modulasi, tetapi bebas frekuensi sinyal modulasi yang diatur oleh frekuensi modulator (Wikipedia, 2019).

Radio yang berbentuk digital ini disebut juga dengan radio Internet karena untuk mengakses radio streaming harus menggunakan media internet. Jangkauan radio internet sangat luas karena bersifat global, berbeda dengan radio konvensional yang jangkauannya terbatas karena menggunakan antenna untuk mencapai jangkauan sinyal. Dengan adanya radio internet tidak ada lagi masalah jarak dan waktu untuk mendengarkan siaran radio yang ingin didengarkan (Amry Daulat Gultom, 2015).

Sistem transmisi berbasis IP audio memudahkan sebuah stasiun radio FM untuk melakukan kegiatan siaran luar dengan lebih efisien dari segi waktu dan perangkat. siaran atau pemograman radio FM dapat dipancarkan dari luar studio dengan menggunakan media transmisi berupa Internet Protokol (IP) yang langsung terhubung pada transmitter radio FM. Dimana jarak lokasi antara studio luar dan Transmitter radio FM jauh, bisa dikatakan lebih dari $1 \mathrm{~km}$. Prinsip yang sama dengan sistem Studio to Transmitter Link (STL) hanya berbeda dari segi kebutuhan jumlah perangkat yang banyak dan tingkat kesulitan dalam pemasangan dan pengoperasiannya (Caka Gatot Priambodo, 2019).

\section{METODE PENELITIAN}

Pada penelitian ini metode yang digunakan adalah deskriptif dengan menyajikan hasil penggunaan sistem dan analisa Comrex Access Portable dan FeenPhone dalam format siaran nasional radio FM. Hasil yang didapat akan menggambarkan bagaimana efektif dan efisiennya penggunaan Comrex Access Portable dan FeenPhone dalam mendukung kegiatan siaran nasional radio FM yang memaksimalkan sumber daya jaringan radio FM nya yang tersebar di beberapa kota besar di Indonesia.

\section{Instrumen Penelitian \\ IP address}

Internet Protocol Address (Alamat IP) Internet Protocol Address atau alamat IP yang bahasa awamnya bisa disebut dengan kode pengenal komputer pada jaringan. Yang merupakan kode vital dalam dunia internet. Karena alamat IP dapat dikatakan sebagai identitas dari pemakai internet, sehingga antara satu alamat dengan alamat lainnya tidak boleh sama. Internet protocol (IP) pada awalnya dirancang untuk memfasilitasi hubungan antara beberapa organisasi yang tergabung dalam departemen pertahanan amerika yaitu Advanced Research Project Agency (ARPA). Sebelum terciptanya internet protocol, jaringan memiliki peralatan dan protocol tersendiri yang digunakan untuk saling berhubungan. Kemudian dibuatlah suatu protocol yang dapat dapat digunakan secara umum untuk menyatukan berbagai perbedaan dalam penggunaan perangkat yang terhubung didalam jaringan. Protocol tersebutlah yang sampai saat ini masih mendominasi dalam pemakaiannya oleh masyarakat banyak yaitu Internet Protocol version 4 (IPv4) (Maria Ulfa, Muhammad Sobri, Iin Seprina, 2014).

IP address versi 4 (untuk selanjutnya cukup disebut IP address) dibentuk dari 32 bit bilangan biner, yang dibagi atas 4 bagian. Setiap bagian panjangnya 8 bit. Contoh IP address sebagai berikut : 01000100100000011111111100000001

Apabila setiap bagian kita konversikan ke bilangan decimal maka IP address di atas menjadi : 68.128.255.1. 
Bentuk penulisan IP address di atas dikenal dengan notasi "doted decimal". IP address bentuk decimal inilah yang kita gunakan sebagai alamat host. Lembaga yang mengatur alokasi IP address di berbagai Negara adalah IANA (Internet Assigned Numbers Authority). Jumlah total IP address sekitar 4 milyar buah. IP address ini tidak semuanya dapat digunakan sebagai IP address untuk host. Ada yang digunakan untuk keperluan khusus, seperti untuk keperluan alamat network, alamat broadcast, alamat localhost, LAN, dan sebagainya. Menurut IANA, IP address berikut ini dicadangkan untuk keperluan jaringan intranet atau LAN.

- Begins with 10. (i.e. 10.0.0.0 through to 10.255.255.255)

- Begins with 127.

- Begins with 169.254.

- Begins with 172.16. through 172.31.

- Begins with 192.168.

IP address yang digunakan untuk keperluan LAN/intranet disebut private IP address. Sedangkan IP address yang digunakan untuk keperluan Internet disebut public IP address (Rifkie Primartha, 2019).

Tabel 1. Private IP address

\begin{tabular}{|c|c|}
\hline Kelas & IP address \\
\hline A & $10.0 .0 .0-10.255 .255 .255$ \\
\hline B & $172.16 .0 .0-172.31 .255 .255$ \\
\hline C & $192.168 .0 .0-192.168 .255 .255$ \\
\hline
\end{tabular}

\section{Comrex Access Portable}

Sistem codec Comrex ACCESS dengan teknologi BRIC (Broadcast Reliable Internet Codec). Produk ACCESS adalah hasil penelitian kami selama bertahun-tahun tentang status jaringan IP dan algoritme pengkodean audio. Harapan kami adalah bahwa teknologi ini akan membebaskan imajinasi pengguna, memungkinkan siaran yang lebih kreatif dan menghibur dari lokasi yang lebih beragam dan menarik.

ACCESS 2USB Portable menyediakan tautan audio dupleks penuh yang kuat, berkualitas tinggi, rendah penundaan melalui jaringan IP yang menantang seperti Internet publik.

Inti dari ACCESS disebut BRIC; Menyiarkan Codec Internet yang Andal. Meski banyak tantangan masyarakat Internet menyajikan, ACCESS dirancang untuk bekerja di sebagian besar koneksi yang tersedia dan memungkinkan menjadi yang terbaik untuk koneksi yang andal.

BRIC adalah teknologi terobosan. Perangkat keras BRIC mengirimkan audio melalui Internet publik dengan banyak cara yang telah dilakukan oleh codec ISDN dan POTS di masa lalu (Thomas O. Hartnett, 2007).

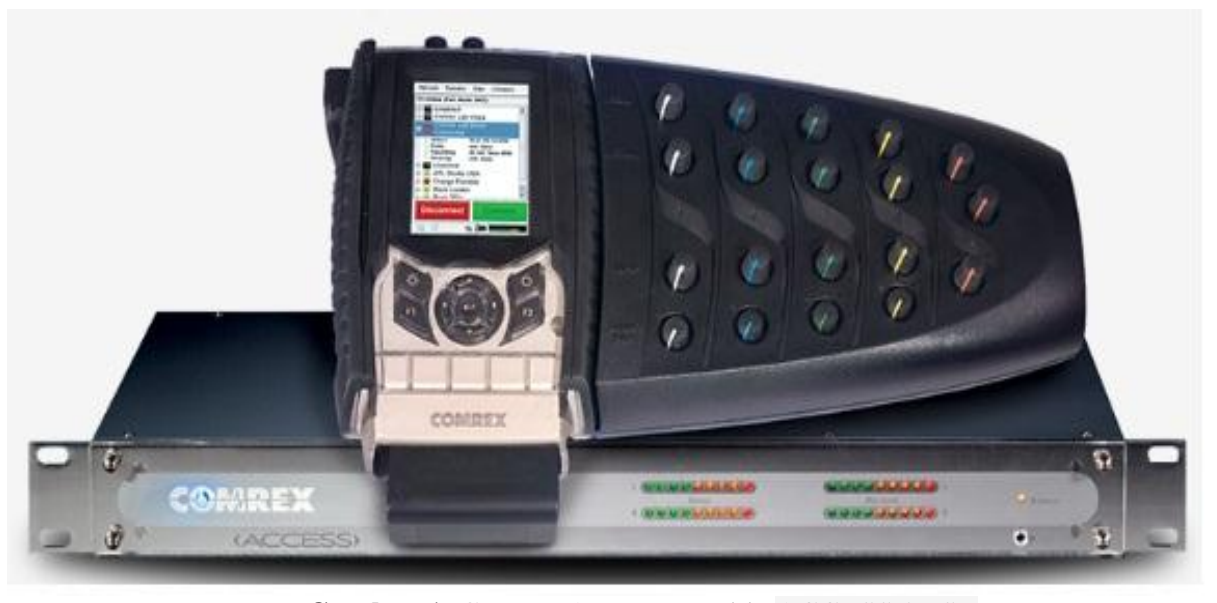

Gambar 1. Comrex Access Portable ACCESS 2USB

(Sumber: Thomas O.Hartnett, 2007) 


\section{FeenPhone}

FeenPhone memungkinkan audio yang diucapkan dupleks asli dengan kualitas ultra tinggi secara real time saat melakukan media langsung dengan orang lain di lokasi terpencil. Ini sudah digunakan oleh penyiar radio dan penyiar radio Internet untuk audio pertunjukan langsung yang bagus. Ini digunakan oleh podcaster untuk membuat acara dengan banyak pembawa acara di mana pembawa acara tinggal terpisah ribuan mil. FeenPhone dapat diadaptasi untuk panggilan telepon berkualitas sangat tinggi di perangkat seluler. FeenPhone juga dapat digunakan untuk menerima panggilan pada acara panggilan masuk, dengan kualitas audio yang lebih baik daripada program voice-over-Internet lainnya, dan dengan kualitas yang jauh lebih tinggi daripada telepon. Ini juga dapat digunakan oleh jurnalis di lapangan untuk mengajukan laporan langsung, oleh pembawa acara radio yang melakukan wawancara "man on the street" dan untuk remote langsung dari acara olahraga dan lainnya (Michael W.Dean, 2014).

FeenPhone adalah perangkat lunak pro untuk audio berkualitas tinggi. Ini lebih bergantung pada koneksi Internet yang solid dan berdedikasi daripada program VoIP tipe konsumen yang terdengar biasa-biasa saja. Organisasi media profesional menggunakan perangkat keras \& perangkat lunak yang mahal melalui koneksi Internet sekali pakai khusus untuk menyambungkan audio lisan langsung untuk siaran radio langsung melintasi mil-mil. Anda dapat mendekati kualitas tersebut secara gratis dengan FeenPhone, tetapi Anda tidak dapat mengunduh file besar secara bersamaan di koneksi Internet rumah. Untuk hasil kualitas siaran terbaik, jangan melakukan apa pun di komputer atau jaringan anda saat menggunakan FeenPhone (Michael W.Dean, 2015).



Gambar 2. FeenPhone

(Sumber: Michael W.Dean, 2015)

\section{HASIL DAN PEMBAHASAN}

\section{Implementasi Sistem}

Adaptasi siaran radio FM komersil menerapkan skema siaran radio FM secara nasional menggabungkan jaringan radio FM nya yang dimiliki perusahaan radio FM tersebut di beberapa kota besar di Indonesia. Ini dilakukan agar tidak terjadi kerumunan atau kehadiran orang atau karyawan dalam jumlah yang banyak dalam waktu yang bersamaan sehingga dapat memangkas jumlah karyawan yang hadir di kantor area studio onair menjadi 50\% hingga 60\% dan tetap menerapkan protokol kesehatan. Pemberlakuan adaptasi siaran radio FM ini berlangsung sejak pertengahan Maret 2020 hingga sekarang, sehingga diharapkan dapat meminimalisir penyebaran virus Covid-19 di area perusahaan radio FM komersil tersebut. Walaupun kehadiran karyawan di area kantor dibatasi hingga 60\% tetapi kuantitas dan kualitas siaran radio FM komersil tetap terjaga dengan baik.

Siaran radio FM secara nasional ini menggunakan media jaringan IP (Internet Protocol) audio dengan menambahkan perangkat keras yakni Comrex Access Portable dan perangkat lunak yakni FeenPhone. Kualitas audio yang dihasilkan dari Comrex Access Portable dan FeenPhone ini akan 
diteruskan ke sistem konfigurasi radio FM yang kemudian dipancarkan melalui frekuensi radio FM masing-masing kota besar di Indonesia. Berikut ini gambar penggabungan radio FM dalam skema siaran radio FM secara nasional.



Gambar 3. Gabungan radio FM dalam skema siaran radio FM secara nasional

\section{Hasil Uji Sistem}

Pengukuran kualitas Comrex Access Portable dan FeenPhone yang tersambung menggunakan jaringan IP (Internet Protocol) pada kota-kota besar di Indonesia, seperti Jakarta, Semarang, Bandung, dan Surabaya. Dalam pengukuran kualitas Comrex Access Portable ini menu statistik yang dianalisis adalah Peer Stats yang berupa grafik (Graph) dan numerik (Numeric). Sedangkan dalam pengukuran kualitas FeenPhone yang dianalisis yakni Input Buffer dan Buffer Target.

\section{Comrex Access Portable Statistik}

Koneksi Comrex Access Portable di kota Semarang yang berperan sebagai Client atau Tx (Transmitter) dalam penyajian graph warna biru menunjukkan aktivitas Target, Jitter Buffer dan Delay, sedangkan penyajian numeric menunjukkan proses aktivitas koneksi. Hasil grafik statistik pada Comrex Access Portable (Tx) menggunakan jaringan IP (Internet Protocol) dimana delay pada Tx Delay menunjukkan nilai 46,0 ms atau dalam (s) yakni 46,0/1000 $=0,046 \mathrm{~s}$ (Tx Delay), waktu yang tertera pada Tx Delay ini dapat dikategorikan Bagus pada sisi transmit (Tx) dalam kualitas siaran radio FM.. Nilai Tx Delay dapat berubah menyesuaikan bandwidth yang ada pada jaringan IP (Internet Protocol) tersebut.

Sedangkan untuk Rx Delay menunjukkan nilai $26,0 \mathrm{~ms}$ atau 0,026 s. Waktu ini dapat dikategorikan bagus pada sisi penerima ( $\mathrm{Rx}$ ) dalam kualitas siaran luar pada stasiun radio FM karena masih di bawah 1 sekon. Sedangkan Target Rx Delay menunjukkan nilai 22,2 ms atau 0,0222 s. Untuk Frame Loss yang menunjukkan nilai 0,0\%, persentase nilai Frame Loss ini dapat dikategorikan Sangat Bagus dari kategori degradasi dengan packet loss 0,0\%. Sedangkan untuk kategori Bagus dari kategori degradasi dengan packet loss antara $0,1 \%-3 \%$.

Berikut ini gambar Comrex Access Portable (Client-Tx) dengan menggunakan jaringan IP (Internet Protocol) pada tanggal 27 Agustus 2020 di kota Semarang, Indonesia. 


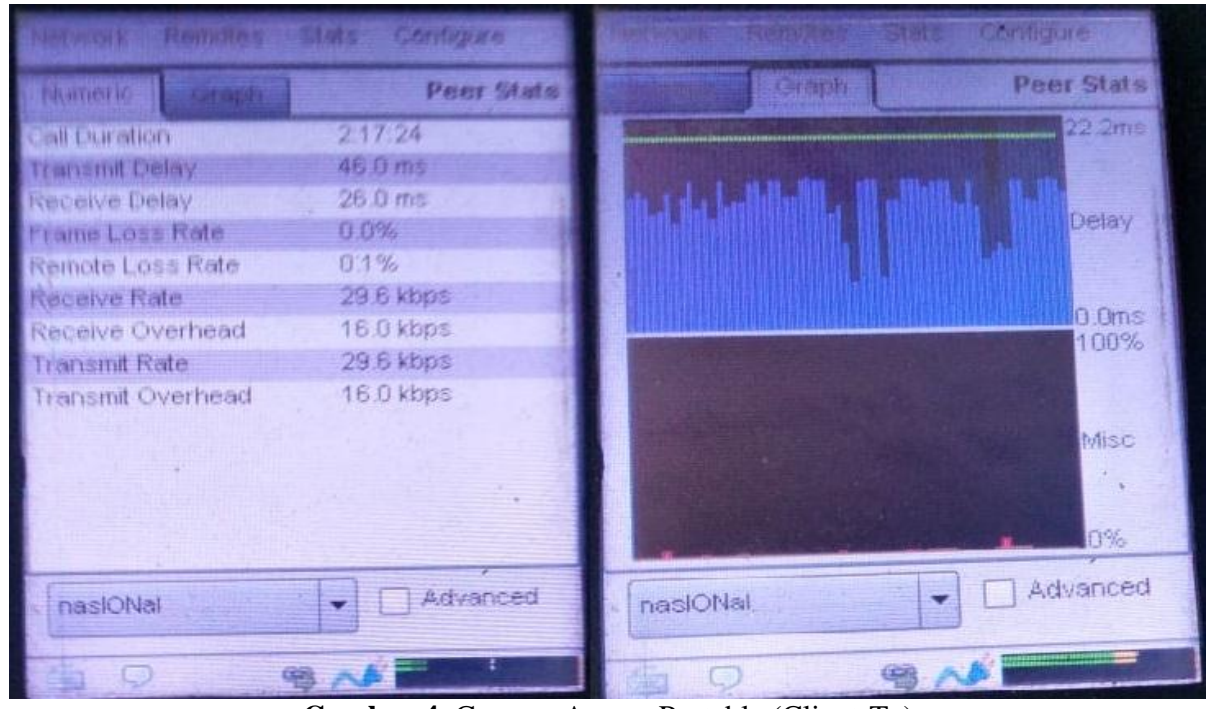

Gambar 4. Comrex Access Portable (Client-Tx)

\section{FeenPhone Statistik}

Penyajian Input Buffer pada FeenPhone Client di kota Bandung pada tanggal 26 Juni 2020 yakni $50 \mathrm{~ms}$, sedangkan Buffer Target yakni $150 \mathrm{~ms}$, ini menunjukkan koneksi jaringan Internet dan perangkat komputer pada FeenPhone Client dikategorikan dalam kualitas audio Bagus dan low enough latency pada kualitas siaran radio FM. Berikut ini gambar FeenPhone Client di kota Bandung pada tanggal 26 Juni 2020.

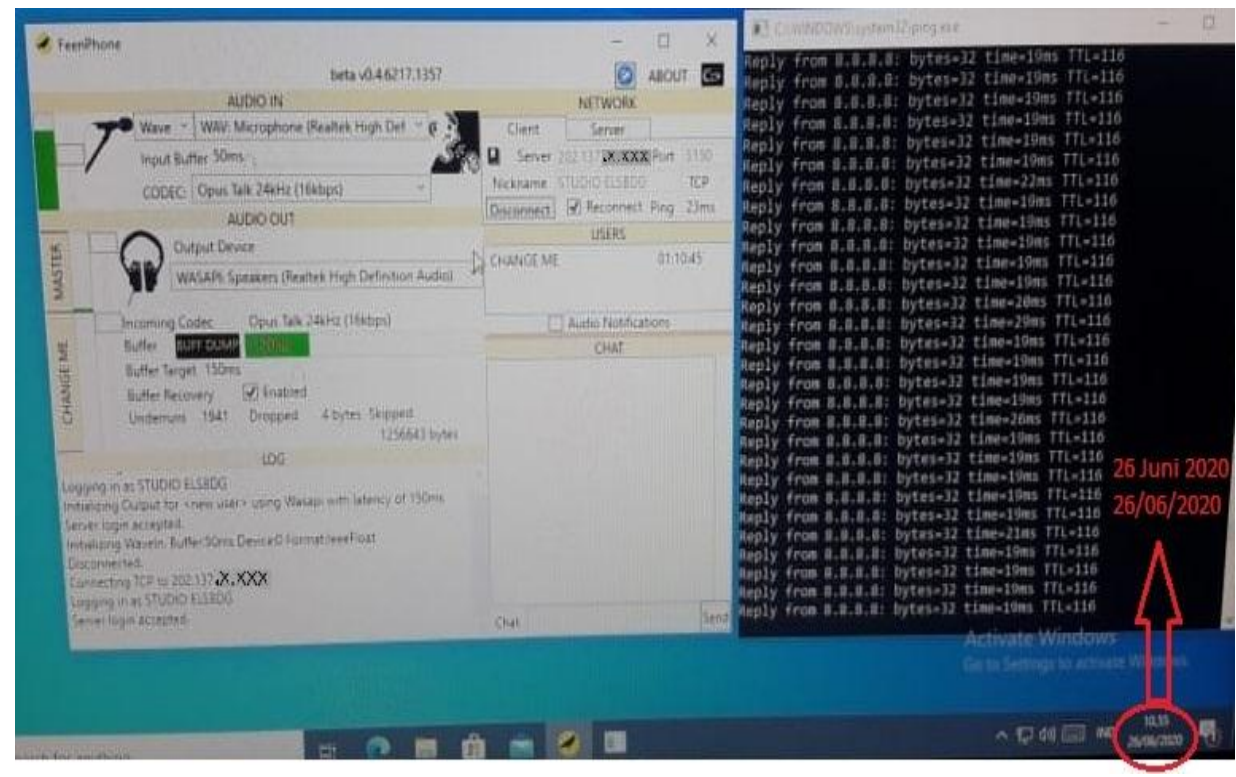

Gambar 5. FeenPhone Client di kota Bandung

Sedangkan untuk FeenPhone Client di kota Surabaya pada tanggal 03 April 2020 tertera Input Buffer pada yakni $50 \mathrm{~ms}$, sedangkan Buffer Target yakni $150 \mathrm{~ms}$, kondisi ini juga menunjukkan koneksi jaringan Internet dan perangkat komputer pada FeenPhone Client di kota Surabaya dikategorikan dalam kualitas audio Bagus dan low enough latency pada kualitas siaran radio FM. Berikut ini gambar FeenPhone Client di kota Surabaya pada tanggal 03 April 2020. 


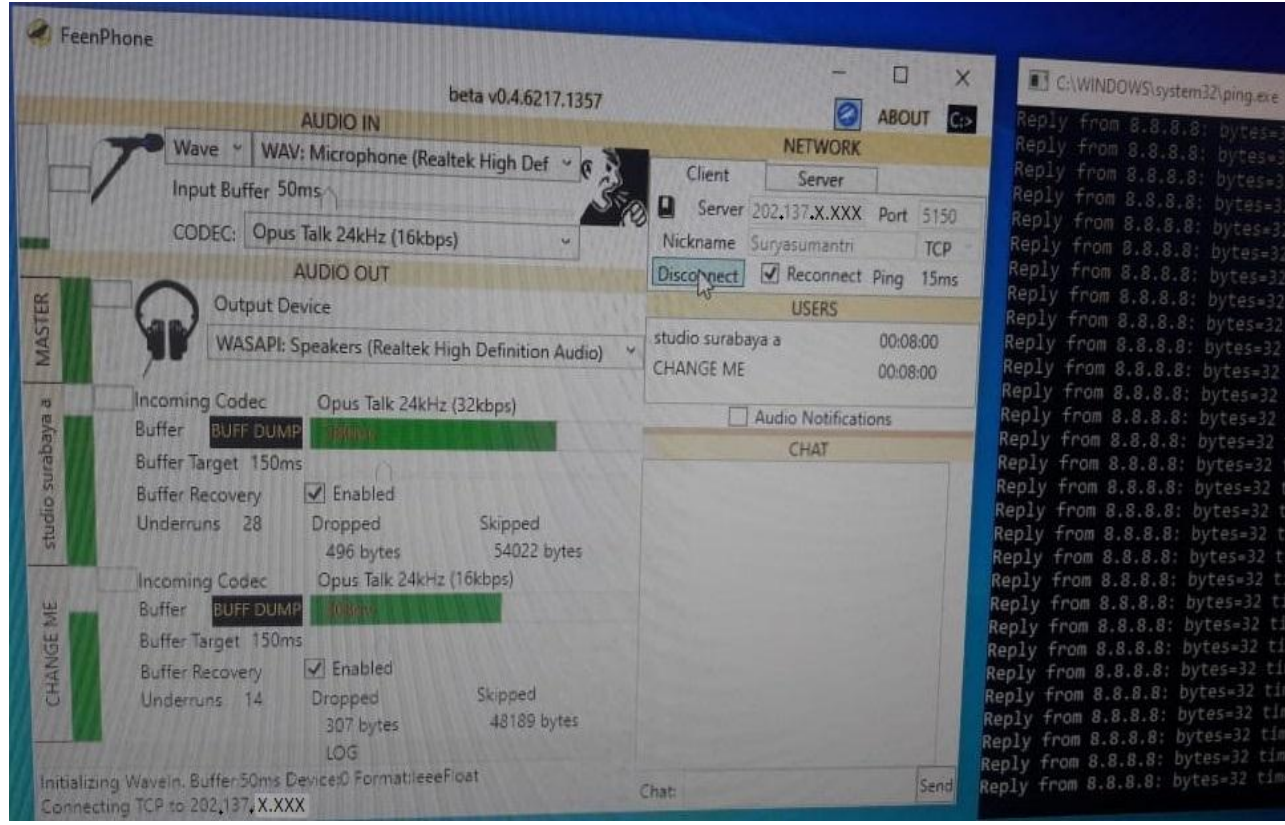

Gambar 6. FeenPhone Client di kota Surabaya

\section{SIMPULAN}

Siaran radio FM secara nasional ini mampu beradaptasi terhadap penerapan Protokol Kesehatan Covid-19 dalam upaya meminimalisir penyebaran virus Covid-19 serta mencegah tidak terjadi kehadiran orang atau karyawan dalam jumlah yang banyak dalam waktu yang bersamaan di area perusahaan. Dengan menggunakan jaringan IP (Internet Protocol) audio pada Comrex Access Portable dan FeenPhone serta sistem konfigurasi radio FM maka penerapan Protokol Kesehatan Covid-19 dapat dilaksanakan dengan baik dan kualitas audio siaran radio FM yang dihasilkan juga dikategorikan Bagus. Sama hal nya dengan infastruktur jaringan internet kota-kota besar di Indonesia mampu memenuhi kebutuhan akses internet bagi masyarakat disekitarnya.

\section{DAFTAR PUSTAKA}

[1] Wikipedia. "Radio fm". Internet: https://id.wikipedia.org/wiki/Radio_fm,

[2] Amry Daulat Gultom. "Kajian Implementasi Radio Siaran Digital di Indonesia". Buletin Pos dan Telekomunikasi Vol. 13 No.2 (2015) 133-150. http://media.neliti.com/media/publications/41213-IDkajian-implementasi-radio-siaran-digital-di-indonesia-study-of-digital-radio-bro.pdf ,

[3] Caka Gatot Priambodo. "Penerapan Comrex Access Portable Berbasis IP Audio Untuk Siaran Luar Radio FM", Prosiding SEMNAS RISTEK 2019 Universitas Indraprasta PGRI Jakarta, P-ISSN: 2527-5321 EISSN: 2527-5941, pp. 094-099.

[4] Maria Ulfa, Muhammad Sobri, Iin Seprina. "Analis Perbandingan IPV4 dan IPV6 Dalam Membangun Sebuah Jaringan”, Prosiding SNIT 2014 Bina Sarana Informatika Kaliabang, Vol 1 No 1, pp. 342-346. [5] Rifkie Primartha. Manajemen Jaringan Komputer (Teori dan Praktik), Bandung: Informatika Bandung, ISBN: 978-602-6232-98-4, 2019, 141-142.

[6] Thomas O. Hartnett. “Access Portable 2usb Manual - ACCESS-2USB.pdf”. pp. 11-12. Internet: https://www.comrex.com/wp-content/uploads/2015/11/ACCESS-2USB.pdf,

[7] Michael W.Dean. "Uses for FeenPhone". Internet: https://feenphone.com,

[8] Michael W.Dean. "FeenPhone Full Manual". Internet: https://feenphone.com/ 2015/01/26/feenphonefull-manual/, 